$\xi=-1$

\title{
Evaluation of Entrepreneurship Education on Development Program of Product Sorghum
}

\author{
Endang Noerhartati ${ }^{1 *}$ \\ ${ }^{1}$ Universitas Wijaya Kusuma Surabaya, Indonesia \\ *Corresponding author Email: endang_noer@uwks.ac.id ; endang.noerhartati@gmail.com
}

\begin{abstract}
This study aims to evaluate and expand the educational entrepreneurship program based on sorghum products. Education entrepreneurship is a compulsory subject for students Agroindustrial Technology Department. Sorghum is one of the potential industrial materials as raw material of entrepreneurship activities. Data were taken through observation, questionnaire, and interview on sixth semester students. Observations focused on responses from practice, responses to commission business opportunities, and observed the output of beginner entrepreneurs practiced. Data were analyzed statistically, to improve the entrepreneurship education process and to develop the sorghum business in Indonesia. In the education process is accompanied by Center for Sorghum Entrepreneurship (CSE). The results achieved create new educated sorghum-based entrepreneurs, produce healthy entrepreneurship products, and mentoring processes by CSE should be implemented continuously in the development of entrepreneurship education programs and to develop a business of sorghum-based products, so can achieve its goal that is to support the food security and sovereignty program of the Government of Indonesia.
\end{abstract}

Keywords: Sorghum, Entrepreneurship Education, Center for Entrepreneurship Sorghum, Food Security and Sovereignty

\section{Introduction}

Observing entrepreneurship class in Higher Education is always interesting since the courses are considered as "no boundary" (1). The interaction of lecturers and students as well as the results of college practice is a recurring process, which then becomes a material upgrades in the next semester. Nevertheless, the accumulated experience of the repetitive processes can not always answer the problems and issues that evolve rapidly in the real world of business. Therefore, the readiness to deal with the changes is very important, especially in cultivating mental resilience as an entrepreneurial candidate, creating an adaptive business plan, and in corporating creative and innovative processes at the business stages (2).

As a millennial generation, students in this era are familiar with and have been pampered by conveniences provided by digital information technology. Their mindset is different from that of the older generation, primarily because of rapidly connection with the outer world. Therefore, attracting them to the agroindustry sector and to become entrepreneurs requires extra effort.

The entrepreneurship class in Agroindustry Department of UWKS has been held since 2013, focusing on awareness programs and encourage the formation of educated entrepreneurs. Based on the accumulation of experience, this education program is then directed to communicate academic issues related to humanities education, science, technology, commerce, and management education systems. Among of the issues is to formulate the responsibility of academics to answer national food security issue through the development of sorghum commodity as an alternative food. The syllabus is then designed in-line with the goal of the entrepreneurship education program that is to encourage the students to become educated entrepreneurs who are able to develop a food busi- ness based on sorghum commodity in Indonesia. The process of the directional education achievement is a study material for improving and updating the model and approach of entrepreneurial education in agroindustry sector.

Selection of sorghum-based products becomes a special topic. This entrepreneurship education program is also supported by a series of research and community service activities are carried out continuously by Center for Sorghum Entrepreneur (CSE)-UWKS since 2009 up to now. More specifically, the purpose of this study is to develop an entrepreneurship education program and to encourage the students of Agroindustrial Technology Study Program, Engineering Faculty of Wijaya Kusuma Surabaya University to become educated entrepreneurs while developing sorghum-based products.

\section{Literature Review}

The research approach is based on cycles that are interrelated with educational programs in which there are elements of actors, determinants, and educational activities: lecturer, syllabus, budget, equipment, social environment, social system, learning method, evaluation system, education innovation, and monitoring system (3). Each of the elements influences the process and success of the entrepreneurship education program. The element is a system that is dynamically capable of doing continuous improvement to adapt with change and development (see Figure 1.)

Entrepreneurship education involves the process of an individual who has entrepreneurial attitudes, skills, and behaviors to become an economic agent who has the ability to develop a business organization (see Figure 2). In this process, an entrepreneur seeks to understand the gap and tries to fit it with limited opportunities and resources in which the opportunities and resources themselves even have the element of uncertainty (see Figure 3). 


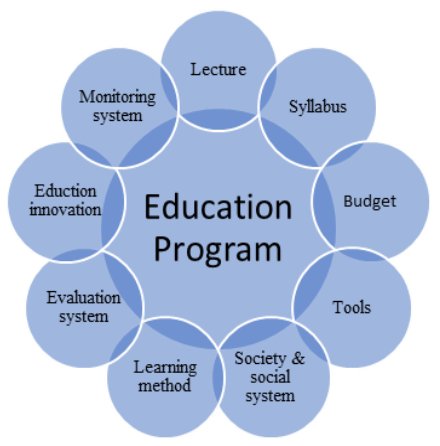

Fig. 1: Management of entrepreneurship class as education program (3).

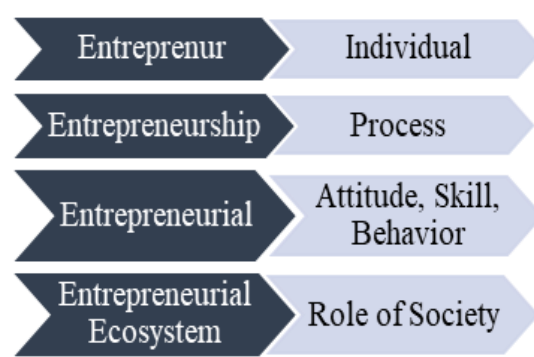

Fig. 2: Terminology of entrepreneur (4).

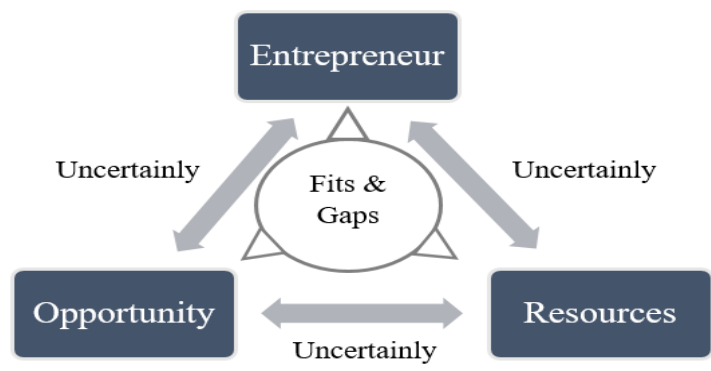

Fig. 3: Process entrepreneurial model (5).

Based on the level of entrepreneurship education, the aims of the education can be categorized as follows: building potential entrepreneur, creating nascent entrepreneur (beginner), and developing dynamic entrepreneur (a new establish business). This category follows the concept of UBESS (6), in which the level of entrepreneurship education is classified into four stages: awareness education, start-up education, continuing education, and education for entrepreneurial dynamism (see Figure 4).

\begin{tabular}{|l|c|c|c|}
\hline \multirow{2}{*}{} & \multicolumn{3}{|c|}{ Stages of entrepreneur } \\
\cline { 2 - 4 } & $\begin{array}{c}\text { Potential } \\
\text { entrepreneur }\end{array}$ & $\begin{array}{c}\text { Nascent } \\
\text { entrepreneur }\end{array}$ & $\begin{array}{c}\text { Dynamic } \\
\text { entrepreneur }\end{array}$ \\
\hline $\begin{array}{l}\text { Awareness } \\
\text { education }\end{array}$ & & & \\
\hline $\begin{array}{l}\text { Start-up } \\
\text { education }\end{array}$ & & & \\
\hline $\begin{array}{l}\text { Continuing } \\
\text { education }\end{array}$ & & & \\
\hline $\begin{array}{l}\text { Education for } \\
\text { entrepreneurial } \\
\text { dynamism }\end{array}$ & & & \\
\hline
\end{tabular}

Fig. 4: UBEEs concept: Objectives of entrepreneurship education (6).

\section{Methodology}

This research is a descriptive qualitative action research $(7 ; 8)$. The participants of the research were three batches of Agroindustrial Technology Study Program students who took entrepreneurship course and attended the sixth semester in 2015, 2016, and 2017 academic year. The data was retrieved through a series of observation, completion of questionnaires, and in-depth interviews. The observation focused on the responses of the students on the teaching learning process in the classroom in accordance with the syllabus, the responses of the students during field practice, and their responses while they were introduced with the business opportunity of sorghum commodity. The research also observed the output of the start-up entrepreneur practiced by the students. The data and information obtained were analyzed statistically and were described to improve the entrepreneurship education process and to develop sorghum business in Indonesia $(9 ; 10)$.

\section{Results}

Entrepreneurship education at UWKS is a compulsory subject with a total of 3 credits and is conducted in the sixth semester. Students may take this course after they have passed the prerequisite courses, namely: (1) Introduction to Agroindustry; (2) Knowledge of Industrial Materials; (3) Engineering and Process Optimization; (4) Packaging and Storage Technology; (5) Marketing Management; (6) Processing Units; and (7) Industrial Project Planning (11). This pattern refers to UWKS Principal Scientific Pattern that is environmental insight and entrepreneurship as stated in the Statute of Wijaya Kusuma Foundation 2017 (12).

With the provision of science and product processing technology, students are actually free to choose commodities that will be developed into products for entrepreneurship activities. Nevertheless, in this study the introduction of sorghum development as a foodstuff was attempted. It is based on the social responsibility of universities in addressing the problems and issues surrounding food security. As it is already known, national rice consumption is always increasing and rice stocks are in a vulnerable condition due to shortage of supply in the country. The solution to overcome rice scarcity with import policy is not without problems because importing rice will actually trigger sustainable problems.

CSE-UWKS has been developing sorghum as foodstuffs through research activities and community services since 2009 up to now. Various research results and community service materials produced by CSE-UWKS become important references for students in entrepreneurship classes, in addition to various references from other sources. The products of the researches are: rice, sorghum flake (13), sorghum noodles (14), various sorghum pastries and bread $(15)$, sorghum syrup $(16 ; 17)$, and sorghum cake and cookies $(18 ; 19)$, soft bran cake and cookies (20). The community service materials are formulated in paperworks and are used in community development activities in the area around sorghum farming (21-24).

In addition, CSE - UWKS also builds and develops Sorghum Entrepreneur Unit (SEU) within the community in the sorghum production center and in the new potential market area for sorghum processed products. SEU groups that have been founded are: SEU seeds, SEU rice, SEU flour, as well as SEU processing units (various cakes, bread, rice, catering). The existence of the SEU becomes part of business network that can be utilized by the students In the syllabus, entrepreneurship courses are formulated as awareness and start-up education aimed at making students become (at least) potential entrepreneurs and striving for students to be nascent entrepreneurs or educated entrepreneurs (25).

In the process of teaching and learning, the students play an active role in accordance with the principle of student-centered learning. Lecturers provide additional time for consultation for those who want to know more about sorghum commodity. Keywords that attract the students to explore various business opportunities of 
sorghum commodities are: sorghum is gluten free food, it is ancient grain that still exists until now, sorghum is a healthy diet, sorghum can be planted on marginal land and it grows well in dry season, and it demands relatively little water compared to rice cultivation. In addition, the business opportunity of sorghum commodity is considered good since there is no business or there are only a few businesses in the field of sorghum processing and the potential market for sorghum processed products are widely open.

The research results of the students' responses to the materials and processes of teaching and learning in entrepreneurship class, in which the students were introduced to sorghum commodity, shows that the students are generally interested to do sorghum-based business. However, some of the students are still not able to calculate whether the business is profitable. The students' responses are provided in Table 1.

The responses of the students generally improve over the last three years (Table 3). However, approximately $2.5 \%$ to $5 \%$ of the students state that they are less interested into the practical activities and assignments. They assume that the activities and assignments as well as the lectures are not conducted in sufficient time and standard by the lecturers. Assessment of the lecturers is particularly the conversion of the assessment questionnaire at the end of the semester, as shown in Table 2.

The output of the learning and teaching process of the sorghumbased entrepreneurship class shows that the goals of it has gradually achieved as expected. Most students' awareness and their capability to see business opportunities from commodities which are not desirable for many people increase. This group of students is a potential entrepreneur. One of the students was even able to formulate her idea in the form of excellent business proposal which was awarded the first winner on the entrepreneurship scientific papers competition.

Some outstanding students have become novice entrepreneurs. They have started their own start-up and become part of SEU sorghum processing units. Some of them specialize in the production of sorghum flour, pastry products such as: brownies, tape, bakpao, sourchip, jenang/ dodol, sticks, courus, and tempe products, as well as ice cream. Two of the students were elected and proposed to receive financial assistance from Kemenristekdikti-RI to begin start-up entrepreneur on jenang and sticks products in 2017 (See Table 3).

The students in this group generally come from the batch of the last academic year. It is likely that they were triggered by CSEUWKS activities which actively helped the members of SEU processing units (e.g. helping them to open new markets for their products). The members of SEU processing units are mostly new small/ medium industries and existing entrepreneurs who founded new business division of sorghum processing.

Table 1: The Students' Responses to the Entrepreneurship Course in Sorghum Business Development 2015-2017

\begin{tabular}{|c|c|c|c|c|}
\hline No. & The Students' Responses & $\begin{array}{c}1^{\text {st group }} \\
\text { (2015) }\end{array}$ & $\begin{array}{l}2^{10} \text { group } \\
(2016)\end{array}$ & $\begin{array}{l}3^{\text {st group }} \\
\text { (2017) }\end{array}$ \\
\hline & Course Material: & \multicolumn{3}{|c|}{ (Percentage) } \\
\hline 1. & Interesting and Complete & 55 & 70 & 80 \\
\hline 2. & Quite Complete & 20 & 15 & 10 \\
\hline 3. & Need Additional Material & 15 & 10 & 5 \\
\hline \multirow[t]{2}{*}{4.} & Less Interesting & 10 & 5 & 5 \\
\hline & Practice / Assignment: & & & \\
\hline 1. & Interesting and Workable & 70 & 70 & 80 \\
\hline 2. & Takes Extra Time & 15 & 10 & 12.5 \\
\hline 3. & Need A Practicum Assistant & 10 & 15 & 5 \\
\hline \multirow[t]{2}{*}{4.} & Less Supportive of Lectures & 5 & 5 & 2.5 \\
\hline & Lecturer: & & & \\
\hline 1. & Very Good & 65 & 70 & 80 \\
\hline 2. & Good & 20 & 20 & 15 \\
\hline 3. & Enough & 10 & 5 & 2.5 \\
\hline 4. & Less & 5 & 5 & 2.5 \\
\hline
\end{tabular}

Information: $\mathrm{n}=20$ (number of the students)

Source: Recapitulation of research questionnaires (2017)
Table 2: The aspects assessed by the students on entrepreneurship lecturers 2015-2017

\begin{tabular}{|c|c|c|c|c|}
\hline \multirow[b]{2}{*}{ No. } & \multirow[b]{2}{*}{ The aspects assessed by the students } & \multicolumn{3}{|c|}{ Score } \\
\hline & & $\begin{array}{l}1^{\text {st }} \\
\text { group } \\
(2015)\end{array}$ & $\begin{array}{l}2^{10} \text { group } \\
(2016)\end{array}$ & $\begin{array}{l}3^{\text {st }} \\
\text { group } \\
\text { (2017) }\end{array}$ \\
\hline 1. & Readiness to give lectures and / or practice / lab. work & 3 & 3,2 & 3,4 \\
\hline 2. & Regularity and order of lectures & 3,5 & 3,5 & 3,7 \\
\hline 3. & Ability to live the classroom & 3,4 & 3,6 & 3,6 \\
\hline 4. & Utilization of media and learning technology & 3,2 & 3,5 & 3,6 \\
\hline 5. & Diversity of test and assessment on learning outcomes & 3,2 & 3,2 & 3,4 \\
\hline 6. & Giving feedback on the task & 3,7 & 3,7 & 3,7 \\
\hline 7. & $\begin{array}{l}\text { Conformity of exam materials / tasks with course } \\
\text { objectives }\end{array}$ & 3,5 & 3,5 & 3,5 \\
\hline 8. & Conformity of given-score with learning outcomes & 3,8 & 3,8 & 3,8 \\
\hline 9. & $\begin{array}{l}\text { Ability to explain the subjects/ topics appropriately and } \\
\text { ability to answers questions }\end{array}$ & 3,5 & 3,7 & 3,7 \\
\hline 10. & Ability to give relevant examples of the concepts taught & 3,4 & 3,6 & 3,6 \\
\hline 11. & $\begin{array}{l}\text { Ability to explain the relevance of the field / topic taught to } \\
\text { other fields /topics }\end{array}$ & 3,5 & 3,5 & 3,5 \\
\hline 12. & $\begin{array}{l}\text { Ability to explain the relevance of the field / topic taught to } \\
\text { the context of life }\end{array}$ & 3,2 & 3,3 & 3,4 \\
\hline 13. & Mastery of current issues in the field being taught & 3,7 & 3,7 & 3,7 \\
\hline 14. & $\begin{array}{l}\text { The use of research results to improve the quality of } \\
\text { lectures }\end{array}$ & 3,8 & 3,8 & 3,8 \\
\hline 15. & Competences achieved after taking the course & 3,7 & 3,8 & 3,8 \\
\hline
\end{tabular}

Information: 1 = Less; 2 = Enough; 3 = Good; 4 = Very Good; $\mathrm{n}=20$ (number of the students)

Source: Recapitulation of research questionnaires (2017)

Brownis sorghum is very potential to be developed as an entrepreneurship product (26), sorghum tape product (27), and sorghum tempe product (28) as a product of sorghum rice fermentation that has potential as entrepreneurship product, sorghum chips product as one of product from sorghum that can be consumed from children to old age and can be developed through entrepreneurship to support food sovereignty in Indonesia (29), bakpao sorghum as one of sorghum-based entrepreneurial products that become the choice of food products (30).

Table 3: The Output of Sorghum-Based Entrepreneurship Program, UWKS 2015-2017

\begin{tabular}{|c|c|c|c|}
\hline No. & 2015 & 2016 & 2017 \\
\hline 1. & $\begin{array}{l}\text { PE: Undergraduate Thesis } \\
\text { - Study on Sorghum } \\
\text { Brownies. } \\
\text { - Study on Sorghum Tape }\end{array}$ & $\begin{array}{l}\text { PE: Undergraduate Thesis } \\
\text { - Study on Sorghum } \\
\text { Tempeh. }\end{array}$ & $\begin{array}{l}\text { PE: Undergraduate Thesis } \\
\text { - Study on Sorghum Bakpao }\end{array}$ \\
\hline 2. & - & $\cdot$ & $\begin{array}{l}\text { PE: Student Competition } \\
\text { - Product development on sorghum } \\
\text { sourchip. } \\
\text { (1t Winner at FT UWKS and } 2^{\text {nd }} \\
\text { Winner at UWKS) } \\
\text { - Product development on sorghum } \\
\text { bakpao. (2 } 2^{\text {nd }} \text { Winner at FT UWKS) }\end{array}$ \\
\hline 3. & - & . & $\begin{array}{l}\text { PE: Presenter in National } \\
\text { Seminar } \\
\text { - Product development on sorghum } \\
\text { bakpao. } \\
\text { - Product development on sorghum } \\
\text { sourchip }\end{array}$ \\
\hline 4. & . & - & $\begin{array}{l}\text { PE: Sorghum Product } \\
\text { Competition } \\
\text { - Product development on sorghum } \\
\text { ice cream } \\
\left(2^{\text {10 }} \text { Winner at UWKS) }\right.\end{array}$ \\
\hline 5. & - & . & $\begin{array}{l}\text { PE: Student Entrepreneur } \\
\text { Program } \\
\text { - Start-up entrepreneur on sorghum } \\
\text { bakpao and Sorchip }\end{array}$ \\
\hline 6. & $\begin{array}{l}\text { NE: Student Entrepreneur } \\
\text { Program } \\
\text { - Start-up entrepreneur on } \\
\text { sorghum stick. }\end{array}$ & $\begin{array}{l}\text { NE: Student Entrepreneur } \\
\text { Program } \\
\text { - Start-up entrepreneur on } \\
\text { sorghum courus. }\end{array}$ & $\begin{array}{l}\text { NE: Student Entrepreneur } \\
\quad \text { Program } \\
\text { - Start-up entrepreneur on sorghum } \\
\text { jenang. }\end{array}$ \\
\hline 7. & - & - & $\begin{array}{l}\text { NE: Student Creativity Program } \\
\text { funded by Kemenristekdikti-RI } \\
\text { - Start-up entrepreneur on sorghum } \\
\text { jenang and stick. }\end{array}$ \\
\hline
\end{tabular}

Note: PE (Potential entrepreneur); NP (Nascent entrepreneur)

The process of entrepreneurship education is a sustainable teaching learning activity which is continuously improved based on the accumulation of experience in which the continuous improvement is the result of performance matrix analysis and the result of four 
main elements, which are then narrated in the Lesson-Learned (see Figure 5). The four main elements are the educational program in the entrepreneurship class, the learning process, the student response and the out-put of the entrepreneurial student profile.

The narration of Lesson-Learned can be in the form of exploring inspiring teaching methods, encouraging the students enthusiasm, providing support for networking, and giving challenges $(31 ; 32\}$.

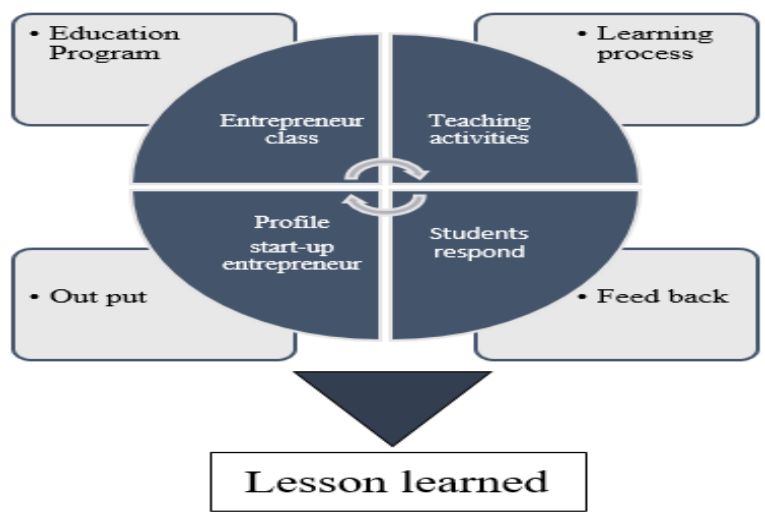

Fig. 5: The Matrix of Entrepreneurship Education at UWKS

The narrated in the Lesson-Learned are:

1. Entrepreneurship is practical learning. It show to be an applicable matter in business. So in this class students must be motivated to create a view business or provide an improvement of an existing business.

2. Succes story always atractive lesson

3. Entering the industry 4.0 era

4. Lecturer needed a more creativity to motivated students

5. Spreading the benefit of entrepreneurship helping people and solution for food security

\section{Conclusion}

The directed educational entrepreneurship program is able to encourage the students to become educated entrepreneurs and that the selection of sorghum-based products in entrepreneurship class should be supported by a series of research activities and continuous community services. The research also suggests that mentoring by the Center for Sorghum Entrepreneurship (CSE)-UWKS should be implemented continuously in the development of educational entrepreneurship program in order to create new entrepreneurs and to develop sorghum-based product business. Therefore, the development of start-up entrepreneur on sorghum-based products, a program which is initiated by UWKS, can achieve its goal that is to support the food security and sovereignty program of the Government of Indonesia.

\section{Acknowledgement}

Thanks to the DG Strengthening Research and Development, Ministry of Research, Technology and Higher Education which has provided "IbIKK" grant funding in 2016 - 2018. Thanks also to the Chairman of the Wijaya Kusuma Foundation and the Rector of UWKS who have granted their permission and support since 2009 until now, so that research on "Development of Sorghum as Alternative Food" can be implemented in a sustainable manner and implemented with the establishment of CSE and SEU.

\section{References}

[1] Dana, L.P. (2004). Handbook of Research on International Entrepreneurship. Northampton, MA: Edward Elgar Publishing Limited.
[2] Jones, C. (2010). Entrepreneurship education: revisiting our role and its purpose. Journal of Small Business and Enterprise Development. Vol. 17, No 4, pp 500-513. available online:

[3] https://doi.org/10.1108/14626001011088697

[4] last visit: 14.01.2017

[5] Lantip, D.P., (2009). E_learning Management: Case study on elearning management in terms of understanding and readiness of lecturers, students' understanding and readiness, infrastructure, policy, human resources development, funding, learning process, control and impact of e-learning system on improving the quality of student learning outcomes at Universitas Negeri Yogyakarta. Universitas Pendidikan Indonesia. Bandung

[6] World Economic Forum. (2009). Educating the next Wave of Entrepreneurs: Unlocking entrepreneurial capabilities to meet the global challenges of the 21st Century. Switzerland: World Economic Forum.

[7] Jeffrey A.T. (1990). New Venture Creation: Entrepreneurship in the 1990s. New Business Enterprises.

[8] Fayolle, A. (2007). Handbook of Research in Entrepreneurship Education, Volume 1: A General Perspective. Northampton, MA: Edward Elgar Publishing Limited.

[9] Kemmis, Stephen and Robin Mc Taggart. (1997). The Action Research Planner. Geelong: Deakin University.

[10] Shirley. (1995). Action Research as on-Going Professional Development. Canberra: Accord.

[11] Stringer, E.T. (1996). Action Research: A Handbook for Practitioners. London: Sage Publications, Inc.

[12] Suwarsih, M., (1999). Action Research Guidelines. Yogyakarta: IKIP Yogyakarta Research Institute.

[13] Edgar E. Troudt, Stuart A. Schulman and Christoph Winkler. (2017). An Evolving Entrepreneurship Simulation as a Vehicle for Career and Technical Education. Journal New Directions for Community Colleges, 2017, No 178, pp 35-44. available online:

[14] https://doi.org/10.1002/cc.20251 last visit: 09.08.2017

[15] Wijaya Kusuma Foundation, (2017). STATUTA 2017. Foundation of Wijaya Kusuma. Surabaya

[16] Noerhartati, E, and Puspitasari, D. (2016). Flake Sorghum (Sorghum sp): Study on Type and Concentration of Sorghum Flour. Proceeding International Conference on Food Agriculture and Natural Resource 2016. pp 83-94.

[17] Noerhartati, E. and Rahayuningsih T. (2015). Optimization of Sorghum Instant Noodles Products: a Study of the Characteristics of Red Sorghum (Sorghum bicolor) and White Sorghum (KD4). Proceeding International Seminar of Resource, Environment, and Marine in the Global Challange 2015 (ISREM 2015). Universitas Wijaya Kusuma Surabaya. pp 50-57.

[18] Noerhartati, E. (2014). Development of Product Variety Cookies, Flakes, Sticks, Mie Sorghum: In Order to Drive the Sorghum Food Industry. Proceedings of Seminar SPRINT 2014. LIPI Yogjakarta. Page 235-238.

[19] Noerhartati, E. and Rahayuningsih T. (2012a). Characterization of Sorghum Liquid Sugar (Sorghum Sp.). Journal of AGROTEKNOLOGI. Vol 7. No. 2. Page 111-119.

[20] Noerhartati, E. and Rahayuningsih T. (2012b). Liquid Sugar of Sorghum Stemp: A Study of Extraction Methods. Proceeding National Seminar of PERTETA Universitas Brawijaya Malang. Page 60-67.

[21] Noerhartati, E. (2010a). Various Industrial Products Made from Wheat and Sorghum. Article on Business Gathering Paper and Technology Gathering. Agriculture Department, Provincial Government of East Java, July 27-28, 2010 - Batu Malang

[22] Noerhartati, E. (2010b). Various Cookies Made from Flour Sorghum (Sorghum bicolor). Paper "Cover Si Unyil TV TRANS 7". Cooperation Program of Agroindustrial Technology Study Program of Engineering-University of Wijaya Kusuma Surabaya with Liputan Si Unyil TV TRANS 7. (2 September 2010)

[23] Noerhartati, E. and Rahayuningsih T. (2016) Soft Bran of Sorghum Potential for High Fiber Supplement Food. Proceeding IFC 2016 "Innovation Of Food Technology To Improve Food Security And Health", Widya Mandala Christian University. Surabaya. Page 131137.

[24] Noerhartati, E., Rahayuningsih, T., Rejeki, F.S., Wedowati, E.R., (2010). Activity Report of IbM Business Group Sorghum Syrup of Sorghum Stemp. Universitas Wijaya Kusuma Surabaya.

[25] Noerhartati, E., Rahayuningsih, T., Rejeki, F.S., (2013). Activity Report of IbM Business Group of Sorghum Flour. Universitas Wijaya Kusuma Surabaya. 
[26] Noerhartati, E., Widiartin, C., Maslihah, Karsono, N.D. (2016). Activity Report of IbIKK Production Center of Sorghum Product at Universitas Wijaya Kusuma Surabaya (Year 1). Universitas Wijaya Kusuma Surabaya.

[27] Noerhartati, E., Widiartin, C., Maslihah, Karsono, N.D. (2017). Activity Report of IbIKK Production Center of Sorghum Product at Universitas Wijaya Kusuma Surabaya (Year 2). Universitas Wijaya Kusuma Surabaya.

[28] Peter Vogel. (2018). From Venture Idea to Venture Opportunity, Journal Entrepreneurship Theory and Practice, Vol 41, No. 6, pp 943-971. available online:

[29] http://journals.sagepub.com/doi/full/10.1111/etap.12234

[30] last visit: 25.04.2017

[31] Kholiq, R. (2015). The Making of Sorghum Brownis: A Study of the Types and Concentrations of Sorghum Flour. Thesis Report. Universitas Wijaya Kusuma Surabaya

[32] Retnowati (2015). Sorghum Tape Making: Study from Long Immersion and Yeast Concentration. Thesis Report. Universitas Wijaya Kusuma Surabaya

[33] Safitri (2016). Making Tempe Sorgum: Study of Type of Sorghum Rice and Packer Type. Thesis Report. Universitas Wijaya Kusuma Surabaya

[34] Irsah M.I. 2017. Entrepreneurship Sorchips (Sorgum chips) To Support Food Sovereignty In Indonesia. Procedding Dies Natalis 36 Universitas Wijaya Kusuma Surabaya

[35] Wahyu P.N, Noerhartati E., Rahayuningsih T. 2017. Potential of Bakpao Sorghum Supports Indonesian Food Diversification. Proceedings Dies Natalis 36 Universitas Wijaya Kusuma Surabaya

[36] Katharina Fellnhofer. (2018). Narratives boost entrepreneurial attitudes: Making an entrepreneurial career attractive?, European Journal of Education, Vol. 53, No. 2, pp 218-237. available online: DOI: 10.1111/ejed.12274. last visit: 29.04.2018

[37] Richard A. Hunt and Kip Kiefer. (2017). The Entrepreneurship Industry: Influences of the Goods and Services Marketed to Entrepreneurs, Journal of Small Business Management, Vol. 55, No. S1 pp 231-255. available online: DOI: $10.1111 /$ jsbm.12329. last visit: 25.09.2017 